Article

\title{
Accepting the Digital Challenge: Business Models and Audience Participation in Online Native Media
}

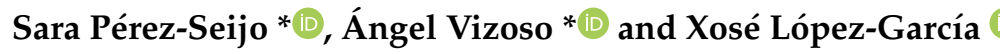 \\ Departamento de Ciencias da Comunicación, Universidade de Santiago de Compostela, \\ 15782 Santiago de Compostela, Spain; xose.lopez.garcia@usc.es \\ * Correspondence: s.perez.seijo@usc.es (S.P.-S.); angel.vizoso@usc.es (Á.V.)
}

Received: 30 October 2020; Accepted: 23 November 2020; Published: 28 November 2020

\begin{abstract}
Since the mid-1990s, many journalistic initiatives have entered the online environment, either as a continuation of brands already consolidated in conventional formats or as native projects of the new medium. In Spain, the online media scene has just completed its first quarter century of life. This said, the aim of this proposal is to present the evolution of the digital native media in Spain in order to compare their current situation with European success stories. For that purpose, we have conducted a comparative case study between three highlighted Spanish digital native news outlets and three from other European countries. The results show a progressive shift towards a member-funded model, while news outlets try to reduce their dependence on advertising. However, the three European natives seem to be more advanced compared to the Spanish cases as these remain still dependent on advertising revenues to stand upright. Furthermore, two models of participation stand out: the user community and, in particular, the model of collaboration networks. Nevertheless, the study reveals how the analyzed European news outlets are changing the role of the reader through innovative forms of participatory interactivity.
\end{abstract}

Keywords: digital journalism; digital native media; business models; audience participation; user interactivity; memberships; subscriptions; community; engagement

\section{Introduction}

Journalism is a communicative activity deeply dependent on technological changes. It has adopted, adapted, and developed some of the most important devices and paradigms, where technology plays a main role. One of the major changes-especially during the last three decades-has been the integration of the Internet both in their routines (Robinson 2010) and in their commercial strategies (Carpes da Silva and Gruszynski Sanseverino 2020). Since the 1990s, we have attended to the creation of online-only journalistic brands as well as the birth of digital versions of renowned media outlets that sought to take as much advantage as possible of this new platform. In this context, we have also witnessed the creation of novel journalistic formats that rely only on this new platform, as could be the case of multimedia infographics (Cores 2004), while others have experienced a growth in its importance, as it has happened, for instance, with fact-checking (Brandtzaeg et al. 2017). Verification, which is a core activity in journalism practice, is now experiencing a rise in terms of audience growth and development of particular tools to detect fake news, both of them directly linked to the emergence of online-based technologies.

As part of a major research project on Spanish online media outlets, this article addresses how three Spanish online-only journalistic brands are adapting themselves to the changing environment of digital journalism by comparing them with three other European examples, each of them with a different strategy. In particular, two particular fields will be reviewed: new ways for monetization of their activities or content and spaces or initiatives for audience participation. All of that in an online 
communicative scenario with a quarter of a century of life and highly influenced by the different economic, cultural, or linguistic characteristics of the Spanish context (Salaverría et al. 2019, p. 25).

\section{Birth and Integration of the Media on the Internet}

The Internet has been a source of change and new chances for journalism (Fortunati et al. 2009). Both journalists and their audiences now have the possibility of interacting, giving feedback, and enriching journalistic content by using the main characteristics of this novel environment: interactivity, multimodality, and hypertextuality (Fondevila 2015). Since the media has been adapting itself to this changing scenario, this has, in fact, favored the development of digital native narrative formats, the emergence of new habits in the relation between journalists and their audiences (Ingram 2014), as well as the appearance of new business models (Carpes da Silva and Gruszynski Sanseverino 2020).

Newsrooms and journalists have abandoned the single-medium model in order to take part in the current multimedia scenario (Saltzis and Dickinson 2008). It all began on 19 January 1994 when Palo Alto Weekly - according to Carlson (2003), the first news publication site on the Internet-started its activity. Notwithstanding, it is necessary to highlight that journalistic brands such as the Chicago Tribune started to share content through the World Wide Web two years before through American OnLine (Díaz-Noci and Meso-Ayerdi 1998). These-among others-were the pioneers in the use of the Internet with a journalistic purpose. Furthermore, between 1994 and 1996, many of the most important journalistic brands started to be part of this digital environment by opening their online spaces (Salaverría 2019). Meanwhile, a new field in the study of communication and journalism started with the birth of the first online media outlets. Thus, in the past 25 years, we have attended to the growth of research focused on the analysis of narrative structures, media management systems, productive routines, and technologies associated exclusively with the news coverage made digitally.

This particular communicative space offers many novel opportunities for professionals and news outlets (Fortunati et al. 2009). As a consequence, digital journalism saw, during its early years, the gradual integration of legacy journalistic brands with the aim of taking advantage of the emerging platform (Cottle and Ashton 1999). Initially, this form of journalism was basically an online reproduction of the printed or broadcasted content following the strategy known as shovelware (Díaz-Noci and Meso-Ayerdi 1998). Over the years, this model moved towards the production of content exclusively for the Internet. Within the framework of convergence processes, media groups have opted for multimedia strategies, where each platform works together with the other ones—such as a print newspaper, radio, or television - but by producing content adapted to the particularities of each channel (Menke et al. 2016).

It should be noted that even though the birth of digital journalism is deeply linked to legacy media outlets, the current news media landscape could not be understood without digital native media outlets, as these have changed the way in which journalism is made in almost every cultural or economic context (Tandoc 2018). In sum, what started by experimenting with the use of the Internet as a new way to share information or try new informative products at consolidated media brands has become a place where countless journalistic projects coexist, regardless of their internal features (Salaverría 2020).

Furthermore, the Internet has provided a fertile ground for journalistic innovation. In this context, over the last two decades, we have attended to the development of different ways of doing and practicing journalism. One of the most relevant examples could be that of so-called slow journalism (Masurier 2015). This trend wants to change the prevailing publishing system for online news, closely linked to breaking news (Usher 2018). In recent years, this long-form and investigative journalistic practice has reached a place of privilege with the emergence of some news media outlets totally committed to a more in-depth approach to information.

In essence, the past two and a half decades have changed the way in which we see journalism. The adoption of the Internet at newsrooms as a publishing space has modified many aspects of this activity as well as the size and the thematic purpose of many media outlets. Thus, with the arrival of 
digital journalism, online media are now global—even those initiatives based on hyperlocal stories (Tenor 2018)—in a context where generalist and specialized projects share the same space.

\subsection{Online Journalism in Spain}

Similarly to what we can see in the international context—and especially for the United States as the starting point of this new way of journalism-online media outlets in Spain began their activity in the mid-1990s. The digital version of a cultural magazine named El Temps-published in the spring of 1994-marked the beginning of Spanish online journalism (Salaverría et al. 2018). A few months later, newspapers such as El Mundo and El Periódico de Catalunya started to publish online through a platform called Servicom (Díaz-Noci 2005), very similar to the American model described above. Since then, the online media landscape in Spain has grown constantly to the present day, with a significant multiplication that took place during the period 2008-2014, coexisting with one of the biggest recessive periods in the history of the country. As a result, there were 3862 digital news media outlets with activity in the last months of 2019 (Negredo et al. 2020).

On the other hand, a study conducted by Salaverría et al. (2019, p. 26) shows how the Spanish online media landscape is closely connected to the larger population centers in areas such as Madrid or Barcelona. Moreover, territories with a proper language — such as Galicia or Basque Country—have a higher number of digital media initiatives than could be expected from its population. Nevertheless, these authors point out the weaknesses of a significant portion of the online journalistic landscape in Spain. Even though there are strong initiatives supported by renowned media outlets, most of them are local and regional ones and, thus, are more likely to suffer during a crisis.

Hence, the online media landscape in Spain reveals a dualism among media outlets with a greater size and budget and those born from small local and private initiatives. In this context, specialized digital native initiatives are remarkably significant because they have enriched the Spanish journalistic environment by covering market niches not explored before.

\subsection{Challenges and Opportunities for Online Journalism}

As pointed before, online journalism-just like other forms of this communicative discipline-has its particularities. However, the changes introduced by the integration of the Internet in newsrooms' daily routines are substantially greater than the shifts added by other technologies. This technological development forced journalists to adapt themselves to acquire new skills and competencies (García Avilés et al. 2004) for dealing with their daily tasks. At this juncture, the main innovation has been the 24/7 production flow and the end of deadlines-or the beginning of a continuous deadline-in the news reporting system (Vonbun et al. 2016).

Furthermore, the media have explored the introduction of many narratives and new forms of journalism, whose spread seemed to be impossible before the arrival of the World Wide Web. This is the case of mobile journalism (Westlund 2013), so-called immersive journalism (de la Peña et al. 2010), interactive information visualization (Weber and Rall 2012), user-generated content (Harrison 2010), or even data journalism (Crucianelli 2013), disciplines that have found a new environment to develop their particular features. Additionally, the emergence of social media (Moon and Hadley 2014; Tandoc and Vos 2015) a decade and a half ago and the progressive deployment of smartphones have opened a new scenario for 21st century media.

This new reality demands not only the adaptation of professional profiles and journalistic routines but also the adjustment of business models and the way in which audiences can consume and take part in the production process (Suárez 2020). Within the following sections, we will explore how three of the main Spanish digital native media outlets are dealing with the challenges of this new era by comparing them with three successful European cases. 


\section{Method}

The aim of this proposal is to present the evolution of the digital native media in Spain in order to compare their current situation-regarding structure capabilities, business models, and user participation possibilities - with European success stories. For that purpose, we have conducted a comparative case study between three highlighted Spanish digital native news outlets-Eldiaro.es, El Confidencial, and El Español-and three from other European countries-Mediapart (France), De Correspondent (Netherlands), and Tortoise Media (United Kingdom). The selection of the European cases was made taking the Digital News Report 2019 as a reference (Newman et al. 2019). Table 1 sumarizes the main features of the six analyzed cases.

Table 1. Digital native media included in the sample.

\begin{tabular}{|c|c|c|c|c|c|c|}
\hline News Outlet & Country & Since & $\begin{array}{c}\text { Annual Billing } \\
\text { (2019) }\end{array}$ & Team Members & $\begin{array}{c}\text { Average Visitors } \\
\text { (Monthly) }\end{array}$ & $\begin{array}{c}\text { Suscribed- } \\
\text { Readers }\end{array}$ \\
\hline Eldiario.es & Spain & 2012 & EUR $6.9 \mathrm{M}$ & 59 & $\begin{array}{c}12.9 \mathrm{M} \\
\text { (September 2020) }\end{array}$ & $+55,000$ \\
\hline El Confidencial & Spain & 2001 & EUR $19.3 \mathrm{M}$ & 27 (managing positions) & $\begin{array}{c}21.1 \mathrm{M} \\
\text { (September 2020) }\end{array}$ & $+18,000$ \\
\hline El Español & Spain & 2015 & EUR 7.2 M & 23 (managing positions) & $\begin{array}{c}23.2 \mathrm{M} \\
\text { (September 2020) }\end{array}$ & $+12,000$ \\
\hline Tortoise Media & United Kingdom & 2019 & EUR $5.1 \mathrm{M}^{*}$ & 19 & N.F. & $+62,000$ \\
\hline De Correspondent & The Netherlands & 2013 & EUR $2.7 \mathrm{M}$ & 82 & N.F. & $+70,000$ \\
\hline Mediapart & France & 2007 & EUR $16.8 \mathrm{M}$ & $\begin{array}{c}87 \text { (49 newsroom, } \\
38 \text { regular collaborators) }\end{array}$ & 5.5.M (March 2020) & $+170,000$ \\
\hline
\end{tabular}

Source: own elaboration. * Annual billing from 2018, last period available. Information on team members was retrieved from each media outlet's webpage. Visitors' data from Tortoise Media and De Correspondent were not found.

This study is based on the assumption that, at the present time, the Spanish digital native media of reference do not have a structural capacity, a business model, and mechanisms for audience participation that can be compared to similar initiatives born in the other European countries. To confirm or reject this, an exploratory study was carried out with the objective of examining each media's characterization in terms of structure, business model, connection between media and readers, role of the user, and mechanisms and strategies to allow interactivity and participation. Interaction was analyzed on the basis of the categories proposed by Masip et al. (2015)—selective interactivity, participatory interactivity, and productive interactivity—and participation was measured taking the models proposed by Masip and Suau (2014) as a reference — catch all, user community, and collaboration networks. This analysis will allow us to figure out similarities and disparities among the above-mentioned cases, as well as strengths and weaknesses of each native.

\section{Results}

The results evidence a progressive shift towards a member-funded model, while news outlets try to reduce their dependence on advertising. In this sense, the three European natives seem to be more advanced compared to the Spanish ones as they still need advertising revenues to stand upright, even though Eldiario.es, El Confidencial, and El Español present mixed models. Moreover, two models of participation stand out: the user community, which is observed in news outlets that promote interaction between users through tools and mechanisms of participatory interactivity-e.g., leaving comments and joining meetings with the newsroom-such as in the case of El Confidencial or Tortoise Media, and especially the model of collaboration networks, in which the community is created by enhancing, to a greater or lesser degree, productive interactivity—writing opinion articles, having a personal blog, being an expert source, and so on-as in the case of Eldiario.es, El Español, De Correspondent, and Mediapart. Table 2 offers a summary of the results found regarding business model and interactivity and participation strategies of the six digital native media. 
Table 2. Main results found during the analysis of the news outlets.

\begin{tabular}{|c|c|c|c|c|c|c|c|}
\hline & & Eldiario.es & El Confidencial & El Español & $\begin{array}{c}\text { Tortoise } \\
\text { Media }\end{array}$ & $\begin{array}{c}D e \\
\text { Correspondent }\end{array}$ & Mediapart \\
\hline & $\begin{array}{c}\text { Business } \\
\text { model }\end{array}$ & $\begin{array}{c}\text { Mixed } \\
\text { (advertisements } \\
\text { and subscribers) }\end{array}$ & $\begin{array}{c}\text { Mixed } \\
\text { (advertisements } \\
\text { and subscribers) }\end{array}$ & $\begin{array}{c}\text { Mixed } \\
\text { (advertisements } \\
\text { and subscribers) }\end{array}$ & Membership & Membership & Membership \\
\hline & $\begin{array}{l}\text { Access to } \\
\text { content }\end{array}$ & Open access & $\begin{array}{l}\text { Mostly open } \\
\text { access, but with } \\
\text { content } \\
\text { restricted to } \\
\text { subscribers }\end{array}$ & $\begin{array}{l}\text { Mostly open } \\
\text { access, but with } \\
\text { content restricted } \\
\text { to subscribers }\end{array}$ & $\begin{array}{l}\text { Restricted to } \\
\text { members } \\
\text { (just preview } \\
\text { to non-members) }\end{array}$ & $\begin{array}{l}\text { Restricted to } \\
\text { members }\end{array}$ & $\begin{array}{c}\text { Restricted to } \\
\text { members }\end{array}$ \\
\hline \multirow{3}{*}{ 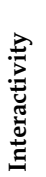 } & Selective & $\bullet$ & $\bullet$ & $\bullet$ & $\bullet$ & $\bullet$ & - \\
\hline & Participatory & - & $\bullet$ & $\bullet$ & - & - & - \\
\hline & Productive & - & & $\bullet$ & & $\bullet$ & $\bullet$ \\
\hline \multirow{4}{*}{ 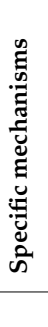 } & $\begin{array}{l}\text { User as } \\
\text { reader and } \\
\text { source }\end{array}$ & & & & & $\bullet$ & \\
\hline & Comments & $\bullet$ & $\bullet$ & $\bullet$ & & $\bullet$ & $\bullet$ \\
\hline & $\begin{array}{l}\text { Meetings } \\
\text { with the } \\
\text { newsroom }\end{array}$ & $\bullet$ & & & $\bullet$ & & \\
\hline & Community & $\bullet$ & $\bullet$ & $\bullet$ & $\bullet$ & • & $\bullet$ \\
\hline
\end{tabular}

Source: own elaboration.

\subsection{Eldiario.es}

Eldiario.es has a mixed business model based on members and advertisements. However, this medium tries to enhance the role, and thus the relevance, of the subscribers by referring to them as the guarantors of the media independence.

Although any user can consult all the news published for free, i.e., there is no paywall to read the content, whatever the topic is, subscribed readers receive a number of benefits in return for their payment. In this regard, the first advantage is the chance of ad-free navigation, as the payment of a subscription constitutes a step towards ending the business' dependence on advertising. The second one is a sort of gratification, since Eldiario.es has opted to highlight the comments left by members on a news story in order to distinguish their contributions from the non-subscribers. Related to this, and according to the medium, their disparate views are taken into consideration by the newsroom.

The fourth benefit is the least common among news outlets: giving the members the opportunity to willingly write opinion articles for the so-called blog "The opinion of the [male and female] members" (La opinion de los socios y socias in Spanish). Finally, although there are other rewards in exchange for the subscription, members can also receive invitations to physical meetings with the newsroom and even with the director, Ignacio Escolar, although these were online during the COVID-19 pandemic.

Therefore, Eldiario.es seeks, through the memberships model, to promote a sense of belonging to a particular community, since readers are not going to pay for reading content, but also to keep the media editorial autonomy and to have the chance to see their own opinions highlighted, either as traditional comments or either as opinion articles on the blog. It should be noted that the above-mentioned advantages can be translated into diverse gratifications that each member experiences first-hand (see Table 3). 
Table 3. Members' advantages in terms of gratifications.

\begin{tabular}{ll}
\hline \multicolumn{1}{c}{ Gratification } & \multicolumn{1}{c}{ Action } \\
\hline Distinction & Leaving comments on the news as a member and being highlighted. \\
\hline Voice & $\begin{array}{l}\text { Publishing personal opinion articles, although with prior media moderation, and joining } \\
\text { meetings with the newsroom. }\end{array}$ \\
\hline Exclusivity & Unlimited access, posting, receiving offers or invitations, and so on. \\
\hline Responsibility & $\begin{array}{l}\text { Guarantors of the media independence thanks to their payments and by voting to } \\
\text { take decisions. }\end{array}$ \\
\hline
\end{tabular}

Source: own elaboration.

Eldiario.es understands that when readers decide to become members, it is because they are committed to the media mission, which is why the medium refers to them as "engaged readers". Furthermore, this digital native directly encourages an active interaction and participation in the media. In fact, we have found three types of interactivity-following the categories proposed by Masip and Suau (2014). On the one hand, we have identified a selective interactivity which is manifested through tools such as newsletters and Really Simple Sindication - RSS—, among others.

On the other hand, there are also options for participatory interactivity, as any reader-with prior free registration-can comment on and, thus, discuss news but also report errata. However, only subscribed readers can participate and vote in surveys to help the media to make decisions-e.g., to restrict comments to just subscribed readers. Finally, the third type of interactivity promoted by Eldiario.es is the productive one, since any user can send cues or information to help the newsroom to investigate what could be an important topic or hidden issue, and furthermore, subscribed members can send their own opinion articles.

In sum, Eldiario.es encourages participation to different degrees, according to the user's involvement, i.e., member/non-member; collaboration, as members' money allows media independence and anonymous readers can send/leak relevant information or data; and even a twofold engagement: (1) media engagement toward autonomy, counterpower, quality, and deep analysis (2) and users' engagement as members of a community where their voices will be heard through user generated content and even, sometimes, also listened to through voting.

\subsection{El Confidencial}

As in the previous case, El Confidencial presents a mixed business model which is both advertising-led and based on subscribed readers. Nevertheless, advertisements are still the main source for funding since, among other factors, the subscription service was released in June 2020 (see Figure 1). Even though most of the content is open-access, subscribed readers have access to "exclusive articles" in return for their commitment. In this regard, El Confidencial is better developing this partly subscriber-funded model under the argument that subscribing allows them, as a news media outlet, to defend the audience's right to know the truth.

It should be noted that this digital native medium tries to enhance a sense of community among all its readers, subscribers or not, through the comments on the news. The only requirement to belong to the so-called influential readers' community (Lectores influyentes in Spanish) is to be registered on the website, which is totally for free. Once users do so, they can already write their opinions in every article they want to. The comments will appear with their name/surname, the total number of articles written so far by each user and the date since when they have been "influential readers", i.e., the date on which they registered on the website. Therefore, compared to the Eldiario.es community, this is completely open to any reader as, subscriber or not, they can be part of it by just creating a free profile on the website.

Furthermore, in order to boost this participatory interactivity and recognize the users' level of involvement-activity and success-El Confidencial has a section called "Community", in which the five most active users and also the five most voted comments appear. This is a strategy to promote 
discussion among the readers and, thus, feedback between them, even though the medium itself remains in the background and acts just as the platform that it, in fact, is.

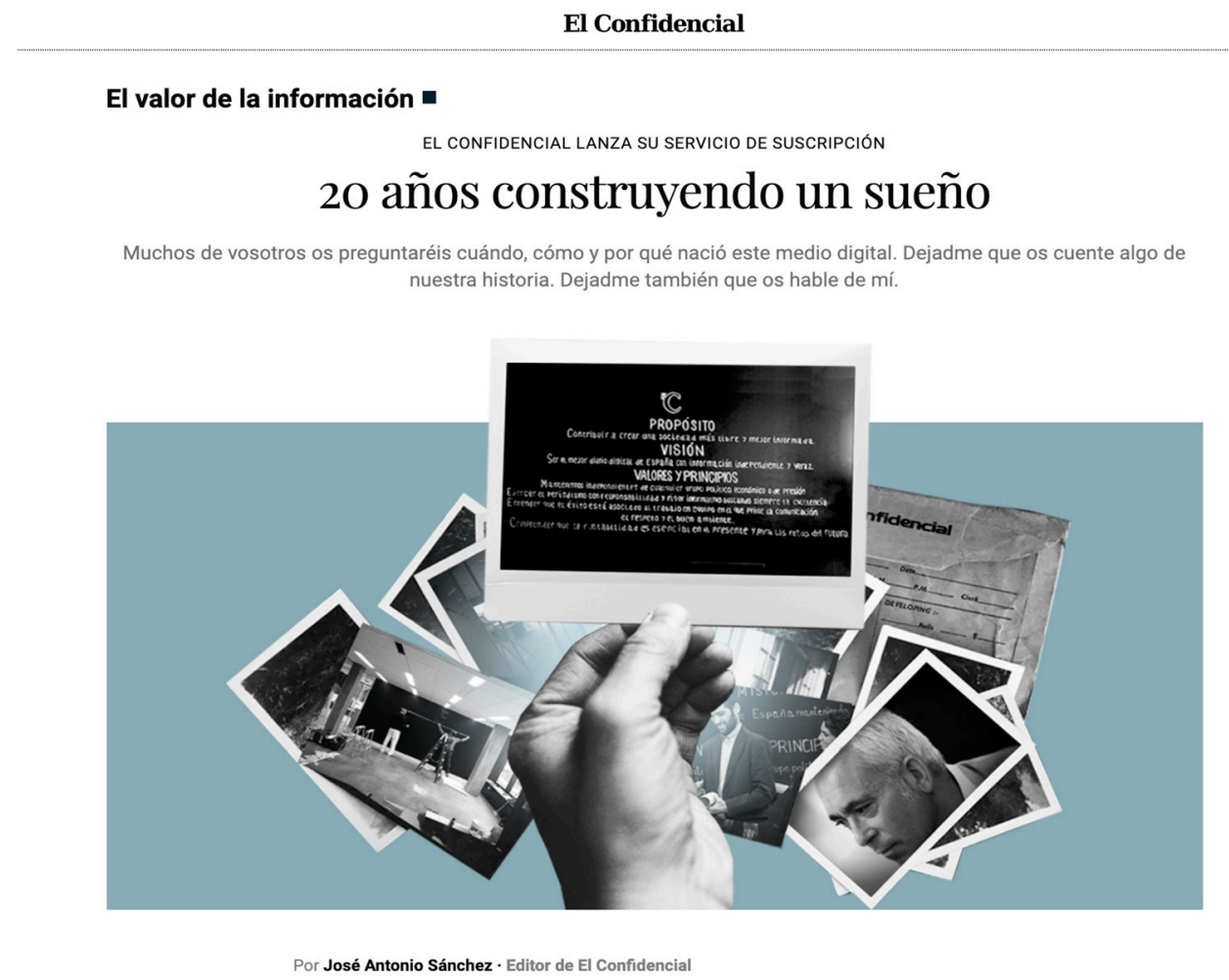

Figure 1. Announcement of the launch of the El Confidencial's subscription service. Source: https: //cutt.ly/vgTKj1K.

\subsection{El Español}

The Spanish digital native medium El Español also has a mixed business model based on both advertisements and subscribers. It should be noted that during the COVID-19 crisis, this online media changed its subscription speech and called on readers to become subscribers to support a "critical and fair coverage" of the pandemic scenario (see Figure 2).

As in the case of Eldiario.es, we have identified three types of interactivity on the web: selective, through mechanisms such as newsletters, RSS, and so on; participatory, by leaving comments on the news; and productive, by writing original posts for the subscriber's blog. By supporting this audience-generated content, the medium gives a voice to its subscribed readers and a digital space to spread their opinions. However, the relationship between the medium and subscribers is still limited and mediated since before publishing the articles, the blog posts are first moderated by the newsroom.

Although El Español does not explicitly refer to a community as such, the online medium fosters a sense of an "exclusive group" through its Subscriber's blog initiative. The opportunity of writing an article on the medium is an experience limited to the most loyal and committed readers, those who choose to pay for the news. In return for their contribution, subscribers obtain a gratification: to have a voice, since they are able to express their thoughts and opinions on an open-access blog. 


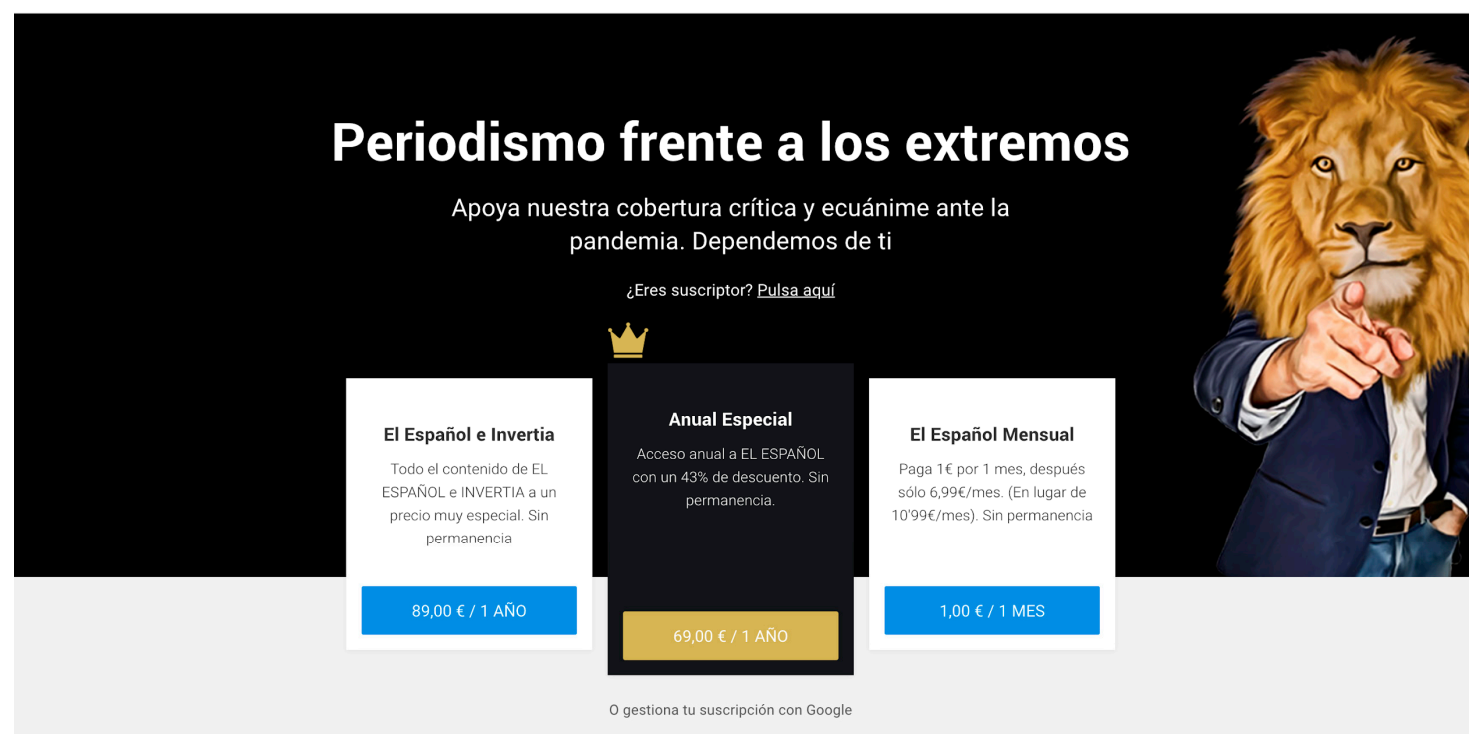

Figure 2. Pandemic-related call for subscribers. Source: El Español.

\subsection{Tortoise Media}

Tortoise Media utilizes a member-based funding model: "created for and with our members" (Tortoise Media 2020a), which offers independence over the conventional advertising model. For reading and interacting, users must be registered as a member, which automatically makes them become part of a restricted community. It should be noted that Tortoise Media avoids the use of the term "subscribers" and, instead, prefers the concept "membership", as it means that the readers belong to or participate in a particular community: "That's why it's not simply about driving readership or just selling subscriptions. It's about membership_-being part of it is more important than just paying for it" (Tortoise Media 2020b).

Being part of Tortoise - as a community - means users will "have a seat at the table". Thus, the idea that every registered user becomes a part of the newsroom and, therefore, that their voices will be heard and taken into consideration is constantly stressed. Even though there is no option for leaving comments on the articles, users can join physical meetings-online during the COVID-19 pandemic crisis—called "ThinkIns", where participants can talk and discuss with the Tortoise team. In this regard, the traditional role of the user is reshaped as the medium enhances a close relationship between the members and the newsroom, dismissing the conventional user to user interactivity through comments on the news.

In exchange for their membership, users obtain two main gratifications: responsibility, as they have contributed to the birth of the medium and now they allow its survival without depending on advertisements, and voice, as they can attend meetings with the newsroom, in which their opinions, suggestions, and comments do matter.

The business and structural model of this digital native is quite different from the conventional digital ones. Tortoise Media emphasizes the role of the members as the main reason for its actual existence, and thus, the medium gives them-or gratifies them with-power and responsibility, since users are not only mere registered readers but also major contributors to the cause: a slow journalism and, presumably, editorial independent project.

\subsection{De Correspondent}

Similar to Tortoise Media, De Correspondent is a digital medium whose access to contents is restricted to members, as it follows a membership-based funding model with no advertisements at all. The De Correspondent philosophy is based on the idea that its journalism must be a conversation between 
journalists, experts, and members. For that reason, members are not seen as passive readers but as potential experts in their field of knowledge or careers.

Therefore, the user's role is reshaped. First, they contribute with money-membership-as guarantors of the medium's autonomy and existence-they pay for journalism and they pay for keeping the project alive. Second, a total innovation: they can become an information source with expertise in a specific field/issue. Thus, De Correspondent not only wants the users' financial contribution (money) but also their knowledge to the medium's benefit (information).

Participation and interactivity are actually encouraged through different possibilities and strategies. First, selective interactivity is present through RSS, newsletters, and so on. Second, participatory interactivity is boosted by leaving comments on the news, by joining discussions and the so-called "Conversations" between members and journalists, and by asking questions and expressing doubts or concerns to the newsroom and experts.

Moreover, De Correspondent fosters productive interactivity too. Members can be an active part during the production process.

1. According to the user's career, job, or field of expertise, the newsroom can contact them in order to ask for help on a specific topic-share knowledge, experiences, and so on.

2. Subscribers can also contact the newsroom if they have information about an issue that should be/deserves to be addressed or investigated.

3. Members, as experts in a specific issue, can be requested to review an article prior to its publication.

4. Members could also be asked to answer other members' questions about a particular topic or story.

5. They can share and post their own opinions and thoughts about particular topics on the so-called "Conversations" section. However, if possible, De Correspondent recommends mentioning sources and adding references. Thus, members become contributors, participants, and even collaborators.

In sum, De Correspondent is based on a collaborative working model in which users are the audience and sources at the same time. Moreover, the medium encourages discussion and connection among users with similar profiles or common interests through the "Conversations" section, and even the relationship between members and "correspondents", meaning that the communication flow between the medium and the users can be both horizontal—dialogue/source—and vertical—consumer.

Therefore, users' gratifications are stronger than before, since they can leave their conventional passive role as a news reader to become an active participant by providing information, for example, as a starting point to a future article, and spreading their expertise, e.g., as a source or by joining a discussion. In sum, as seen in Table 4, three main gratifications have been identified: responsibility, voice, and acknowledgement.

Table 4. De Correspondent: advantages in terms of gratifications.

\begin{tabular}{|c|c|}
\hline Gratification & Action \\
\hline Responsibility & Acting as donors and even information sources. \\
\hline Voice & Leaving comments, joining "Conversations”, or being sources. \\
\hline Acknowledgement & Being considered as an expert on a specific topic or field. \\
\hline
\end{tabular}

\subsection{Mediapart}

Mediapart describes itself as an independent and participatory newspaper. Full autonomy was achieved in July 2019 when Mediapart shares were sold to a non-profit fund. Since then, its primary means of funding are memberships, its guarantee of freedom and editorial independence. The newspaper has a paywall, so only members can receive full access to the articles published on the web. However, it should be noted that during the COVID-19 crisis, this digital medium allowed free access to pandemic-related information and verified data. 
Mediapart gives members responsibility and power, turning them into an active part of the medium. As members, users can comment on news articles and have their own blogs in "Le Club" to publish opinion articles, a section which, in fact, is open-access even for non-subscribers. Through "Le Club", Mediapart encourages the sense of belonging to a community: a collective of active members who read the newspaper but also contribute with their own opinions beyond leaving comments on the news. "Le Club" is a sort of social network where users can follow other blogs from members, or even journalists, create their own personal network, and communicate privately with other subscribers and even journalists. This is, in fact, a mechanism of productive interactivity, since users generate their own content (user-generated content, UGC) for which they are responsible.

However, there is also participatory interactivity, present through the most common option: comments on the news. Furthermore, users can send documents of public interest to the newsroom via an option named "French Leaks" (see Figure 3). On the other hand, and as usual, RSS and newsletters are available, a sign that there are tools for enhancing selective interactivity too.

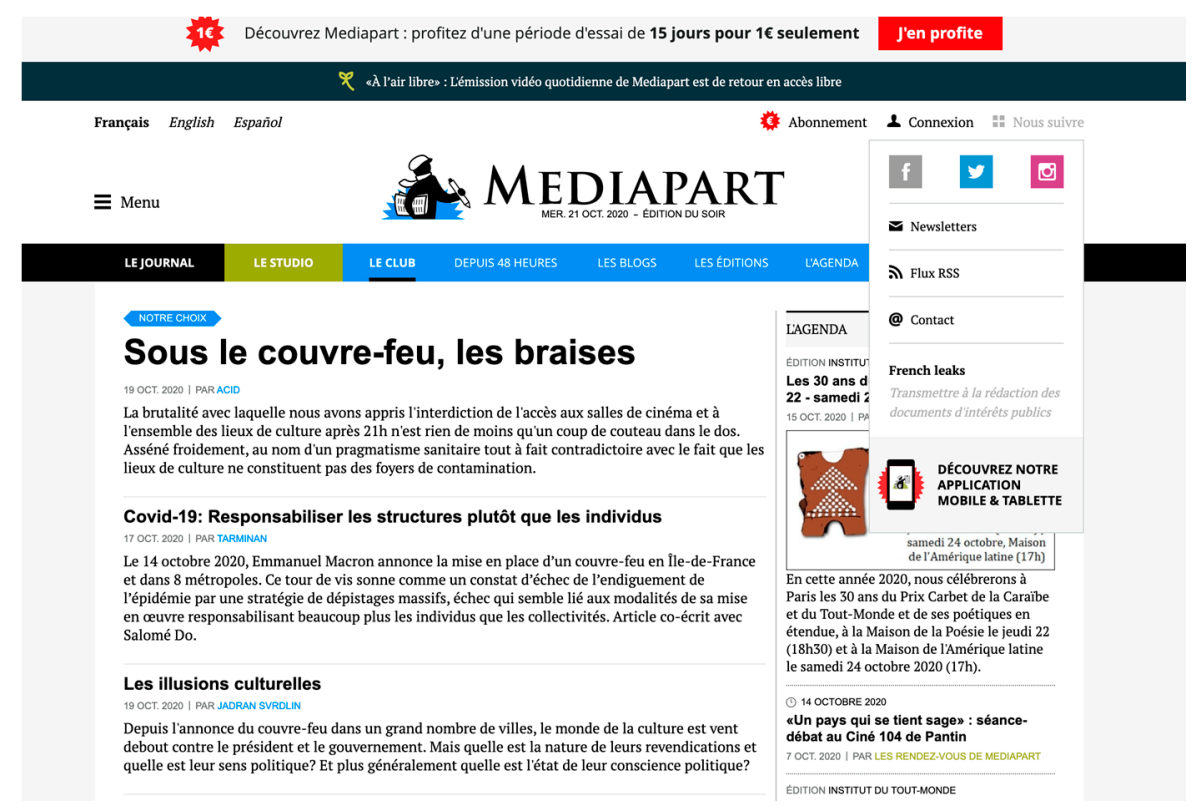

Figure 3. "Le Club" blog section and the "French Leaks" option in the dropdown menu. Source: Mediapart.fr.

In return for their contribution, members receive a two-fold responsibility: firstly, as guarantors of the medium's editorial independence, and secondly, as responsible for their UGC on "Le Club". However, they also receive the gratification of being heard—or, better said, of being read-by others and of being taken into account by the medium, since Mediapart provides them with a specific, personal space to share their own opinions and thoughts. Together with these gratifications, members also obtain distinction, as they can publish on Le Club, and exclusivity, because they are not mere readers but members of a community of users who pay for reading quality and verified information and, if the case, for generating their own content too. In sum, what Mediapart encourages the most is the user's participation and engagement.

\section{Conclusions}

The results show that Spanish digital native media are still rooted in an advertisement-based funding model. Although they are beginning to develop novel subscriptions and community-related formulas, most of the content is still open-access for non-subscribers. Therefore, Spanish digital media still conceive subscribed readers as an alternative financial complement but not the main source of income. As long as this situation lasts, these native media will remain highly dependent on 
advertising and, thus, its editorial independence will continue to be contested. In this regard, Eldiario.es is the exception. This digital native delegates the responsibility for the editorial independence to the subscribed readers. Although its business model is mixed and still highly dependent on advertisement revenues, Eldiario.es seems to be shifting towards a member-based model in which responsibility becomes a gratification in exchange of the user's commitment to the medium's goal: full editorial independence.

However, the situation of the three analyzed European cases is quite different. These natives have completely developed their own member-based funding models in which users are, in fact, the core of each project, since they have contributed to the medium's birth, and now, they keep them alive over time, showing both a high commitment and responsibility towards each news outlet's cause. Here, this responsibility results in a gratification that, therefore, only subscribed readers receive. Furthermore, as only members can read the content, communities are restricted to them, which enhances a sense of exclusivity.

The distinguishing feature is that the members have become guarantors of each medium's independence and, as in the particular case of De Correspondent and Tortoise Media, they also make possible the practice of a deep and quality slow journalism. In return for their commitment to the project, these digital natives promote the belonging of a community of members by giving them a voice - to be heard and read by the journalists and other readers—and even, sometimes, a vote-their thoughts are heard and, occasionally, taken into consideration by the newsroom. Therefore, voice and vote become relevant gratifications, making a difference compared to the conventional model of news outlets.

We have noticed how the three European digital native media have further developed their community models. In this regard, in the Spanish cases, members or users-as it is not always restricted to subscribers-who belong to each media community are less able to share their opinions and have any type of influence on the news production process. While in Spain, subscribers have access to exclusive content-similar to the European studied cases-their ability to contribute with ideas and suggestions is more limited than in media outlets such as De Correspondent or Tortoise Media. Thus, Spanish readers are missing access to such gratification, which is a sort of involvement by having a greater ability to share opinions and thoughts and to vote on relevant decisions, although, as mentioned before, Eldiario.es is implementing such types of strategies.

Moreover, this study reveals how these European native media are changing the role of the reader-now a member-since he or she becomes an active participant. The reason is threefold: members pay a membership, so they contribute financially to the survival of the project; they can participate and contribute with their personal opinions-depending on the case, through comments, discussions, meetings, and posts on a blog; and sometimes, they even can collaborate as expert sources, according to their field of knowledge, as in the case of De Correspondent.

This said, participatory interactivity is more innovative in the case of European native media. The conventional model based on comments on the news, enabling discussion among readers, is suffering a loss of value-in fact, in the case of Tortoise Media, it is non-existent. Instead, media enhance another type of participation based on a closer and more horizontal relationship between the members and the newsroom. To date, among the Spanish digital native media, Eldiario.es is the closest to models such as those presented by De Correspondent and Tortoise Media.

Finally, even though providing quality, verified information is the main objective of the six analyzed media, the European natives highlight the role of the member as the main important element for that purpose, while the Spanish news outlets are a step behind, still rooted in a conventional mindset.

Regarding the limitations of our study, it is necessary to stress the nature of the reviewed sample. As readers could notice, a convenience sample was selected, in order to highlight the existence of different funding and business models across the digital native media outlets landscape in Europe. As a consequence, we cannot share our conclusions neither as a trend nor a norm. These are just a picture of different ways of facing the challenges of initiating journalistic online projects. There is room 
for future research on this subject by not only exploring, in more depth, business models' features but also relating this financial perspective with its implications for news-making processes.

Author Contributions: Conceptualization, S.P.-S., Á.V. and X.L.-G.; Investigation, S.P.-S. and Á.V.; Methodology, S.P.-S.; Project administration, X.L.-G.; Resources, Á.V.; Supervision, X.L.-G.; Writing-original draft, S.P.-S. and Á.V.; Writing - review \& editing, S.P.-S, Á.V. and X.L.-G. All authors have read and agreed to the published version of the manuscript.

Funding: This article has been developed within the research project "Digital Native Media in Spain: Storytelling Formats and Mobile Strategy (RTI2018-093346-B-C33)", funded by the Ministry of Science, Innovation and Universities (Government of Spain) and co-funded by the European Regional Development Fund (ERDF). Furthermore, authors Sara Pérez-Seijo and Ángel Vizoso are also beneficiaries of the Training University Lecturers' Program (FPU), funded by the Spanish Ministry of Science, Innovation and Universities (Government of Spain).

Conflicts of Interest: The authors declare no conflict of interest.

\section{References}

Brandtzaeg, Petter Bae, Asbjørn Følstad, and María Ángeles Chaparro Domínguez. 2017. How Journalists and Social Media Users Perceive Online Fact-Checking and Verification Services. Journalism Practice 12: 1109-29. [CrossRef]

Carlson, David. 2003. The History of Online Journalism. In Digital Journalism: Emerging Media and the Changing Horizons of Journalism. Edited by Kevin Kawamoto. Lanham: Rowman \& Littlefield Publishers, pp. 31-55.

Carpes da Silva, Giuliander, and Gabriela Gruszynski Sanseverino. 2020. Business Model Innovation in News Media: Fostering New Relationships to Stimulate Support from Readers. Media and Communication 8: 28-39. [CrossRef]

Cores, Rafael. 2004. Infográficos Multimedia: El Mejor Ejemplo de Noticias Hipertextuales. Mediaccionline. Available online: https://infoguay.wikispaces.com/file/view/infografia_multimedia.pdf (accessed on 5 December 2016).

Cottle, Simon, and Mark Ashton. 1999. From BBC Newsroom to BBC Newscentre: On Changing Technology and Journalist Practices. Convergence: The International Journal of Research into New Media Technologies 5: 22-43. [CrossRef]

Crucianelli, Sandra. 2013. ¿Qué Es El Periodismo de Datos? Cuadernos de Periodistas. June 8. Available online: http://www.cuadernosdeperiodistas.com/que-es-el-periodismo-de-datos/ (accessed on 10 December 2016).

Díaz-Noci, Javier. 2005. Historia de Los Cibermedios En España. In Cibermedios. El Impacto de Internet En Los Medios de Comunicación En España. Edited by Ramón Salaverría. Sevilla: Comunicación Social Ediciones y Publicaciones, pp. 21-38.

Díaz-Noci, Javier, and Koldo Meso-Ayerdi. 1998. Desarrollo Del Periodismo Electrónico. El Profesional de La Información 7: 4-11. Available online: http://www.elprofesionaldelainformacion.com/contenidos/1998/ diciembre/desarrollo_del_periodismo_electronico.html (accessed on 15 May 2020).

Fondevila, Joan Francesc. 2015. El uso de hipertexto, multimedia e interactividad en periodismo digital: Propuesta metodológica de ranking de calidad. ZER—Revista de Estudios de Comunicación 19: 55-76. Available online: http://www.ehu.eus/ojs/index.php/Zer/article/view/13488 (accessed on 15 May 2020).

Fortunati, Leopoldina, Mauro Sarrica, John O'Sullivan, Aukse Balcytiene, Halliki Harro-Loit, Phil Macgregor, Nayia Roussou, Ramón Salaverría, and Federico De Luca. 2009. The Influence of the Internet on European Journalism. Journal of Computer-Mediated Communication 14: 928-63. [CrossRef]

García Avilés, José Alberto, Bienvenido León, Karen Sanders, and Jackie Harrison. 2004. Journalists at Digital Television Newsrooms in Britain and Spain: Workflow and Multi-Skilling in a Competitive Environment. Journalism Studies 5: 87-100. [CrossRef]

Harrison, Jackie. 2010. User-Generated Content and Gatekeeping at the BBC Hub. Journalism Studies 11: 243-56. [CrossRef]

Ingram, Mathew. 2014. For Journalists, Interacting with Readers Isn't Just Good Practice-It Could Mean Survival. Gigaom.Com. Available online: https://gigaom.com/2014/04/25/for-journalists-interacting-with-readers-isntjust-good-practice-it-could-mean-survival/ (accessed on 15 October 2020). 
de la Peña, Nonny, Peggy Weil, Joan Llobera, Elias Giannopoulos, Ausiás Pomés, Bernhard Spanlang, Doron Friedman, Maria V. Sanchez-Vives, and Mel Slater. 2010. Immersive Journalism: Immersive Virtual Reality for the First-Person Experience of News. Presence: Teleoperators and Virtual Environments 19: 291-301. [CrossRef]

Masip, Pere, Javier Guallar, Miquel Peralta, Carles Ruiz, and Jaume Suau. 2015. Active Audiences and Journalism: Involved Citizens or Motivated Consumers? Brazilian Journalism Research 11: 234-55. [CrossRef]

Masip, Pere, and Jaume Suau. 2014. Active Audiences and Participation Models in Spanish Media. Hipertext.Net 12: 1-16. Available online: https://www.raco.cat/index.php/Hipertext/article/view/274308/364479 (accessed on 27 October 2017).

Masurier, Megan Le. 2015. What Is Slow Journalism? Journalism Practice 9: 138-52. [CrossRef]

Menke, Manuel, Susanne Kinnebrock, Sonja Kretzschmar, Ingrid Aichberger, Marcel Broersma, Roman Hummel, Susanne Kirchhoff, Dimitri Prandner, Nelson Ribeiro, and Ramón Salaverría. 2016. Convergence Culture in European Newsrooms. Journalism Studies 19: 881-904. [CrossRef]

Moon, Soo Jung, and Patrick Hadley. 2014. Routinizing a New Technology in the Newsroom: Twitter as a News Source in Mainstream Media. Journal of Broadcasting $\mathcal{E}$ Electronic Media 58: 289-305. [CrossRef]

Negredo, Samuel, María Pilar Martínez-Costa, James Breiner, and Ramón Salaverría. 2020. Journalism Expands in Spite of the Crisis: Digital-Native News Media in Spain. Media and Communication 8: 73-85. [CrossRef]

Newman, Nic, Richard Fletcher, Antonis Kalogeropoulos, and Rasmus Kleis Nielsen. 2019. Digital News Report 2019. London. Available online: https://reutersinstitute.politics.ox.ac.uk/risj-review/digital-news-report2019-out-now (accessed on 8 July 2019).

Robinson, Sue. 2010. Traditionalists vs. Convergers: Textual Privilege, Boundary Work, and the Journalist-Audience Relationship in the Commenting Policies of Online News Sites. Convergence 16: 125-43. [CrossRef]

Salaverría, Ramón. 2019. Digital Journalism: 25 Years of Research. Review Article. El Profesional de La Información 28: 280101. [CrossRef]

Salaverría, Ramón. 2020. Exploring Digital Native News Media. Media and Communication 8: 1-4. [CrossRef]

Salaverría, Ramón, María Del Pilar Martínez-Costa, and James Breiner. 2018. Map of Digital News Media at Spain in 2018: Quantitative Analysis. Revista Latina de Comunicacion Social 73: 1034-53. [CrossRef]

Salaverría, Ramón, María del Pilar Martínez-Costa, James G. Breiner, María-Cruz Negreira-Rey, and Miguel-Ángel Jimeno. 2019. El Mapa de Los Cibermedios En España. In Ecosistema de Cibermedios En España. Edited by Carlos Toural-Bran and Xosé López-García. Salamanca: Comunicación Social Ediciones y Publicaciones, pp. 25-49.

Saltzis, Konstantinos, and Roger Dickinson. 2008. Inside the Changing Newsroom: Journalists' Responses to Media Convergence. Aslib Proceedings 60: 216-28. [CrossRef]

Suárez, Eduardo. 2020. How to Build a Successful Subscription News Business: Lessons from Britain and Spain. Oxford. Available online: https://reutersinstitute.politics.ox.ac.uk/sites/default/files/2020-02/Eduardo_ Suarez_Digital_subscriptions_fellowship_paper.pdf (accessed on 9 October 2020).

Tandoc, Edson C. 2018. Five Ways BuzzFeed Is Preserving (or Transforming) the Journalistic Field. Journalism 19: 200-16. [CrossRef]

Tandoc, Edson C., and Tim P. Vos. 2015. The Journalist Is Marketing the News. Journalism Practice 10: 950-66. [CrossRef]

Tenor, Carina. 2018. Hyperlocal News and Media Accountability. Digital Journalism 6: 1064-77. [CrossRef]

Tortoise Media. 2020a. Become a Member. Tortoisemedia.Com. Available online: https://www.tortoisemedia.com/ become-a-member (accessed on 10 October 2020).

Tortoise Media. 2020b. Purpose. Tortoisemedia.Com. Available online: https://www.tortoisemedia.com/purpose/ (accessed on 10 October 2020).

Usher, Nikki. 2018. Breaking News Production Processes in US Metropolitan Newspapers: Immediacy and Journalistic Authority. Journalism 19: 21-36. [CrossRef]

Vonbun, Ramona, Katharina Kleinen-von Königslöw, and Klaus Schoenbach. 2016. Intermedia Agenda-Setting in a Multimedia News Environment. Journalism 17: 1054-73. [CrossRef] 
Weber, Wibke, and Hannes Rall. 2012. Data Visualization in Online Journalism and Its Implications for the Production Process. Paper Presented at 2012 16th International Conference on Information Visualisation, Montpellier, France, July 11-13; pp. 349-356. [CrossRef]

Westlund, Oscar. 2013. Mobile News. Digital Journalism 1: 6-26. [CrossRef]

Publisher's Note: MDPI stays neutral with regard to jurisdictional claims in published maps and institutional affiliations.

(C) 2020 by the authors. Licensee MDPI, Basel, Switzerland. This article is an open access article distributed under the terms and conditions of the Creative Commons Attribution (CC BY) license (http://creativecommons.org/licenses/by/4.0/). 